\title{
Production of Indole-3-Acetic Acid in the Culture Medium of Microalga Scenedesmus obliquus (UTEX 393)
}

\author{
Rosa E. Prieto C.,* Nancy M. Cordoba C., Andres M. Montenegro J. and Gloria E. González-Mariño \\ Facultad de Ingeniería, Campus Universitario Puente del Común, \\ Universidad de La Sabana, Chía, Cundinamarca, Colombia
}

\begin{abstract}
O acido indolacético (IAA) é uma auxina natural e um dos principais reguladores do crescimento de plantas superiores. A quantidade de ácido indolacético extracelular produzida pela cultura de microalga verde Scenedesmus obliquus foi estabelecida por cromatografia líquida de alta eficiência (HPLC). Avaliou-se o efeito de três variáveis de processo na produção de IAA extracelular nestas culturas usando planejamento fatorial $2^{3}$ para uma metodologia de screening. As variáveis de planejamento experimental foram agitação, iluminância (intensidade do fluxo luminoso) e fonte de carvão (mistura $\mathrm{CO}_{2} /$ air v/v (\%)) em três diferentes níveis. A concentração de IAA e a taxa de crescimento específico foram usadas como variáveis de resposta. As análises de HPLC mostraram que em condições experimentais, a quantidade de IAA que foi liberada no meio pela alga S. obliquus depende somente da variável iluminância. Os efeitos da luz e as concentrações de carvão no meio de cultura foram significantes $(p<0.05)$ para uma taxa de crescimento específico.
\end{abstract}

The indoleacetic acid (IAA) is a natural auxin and one of the main growth regulators in higher plants. The extracellular indoleacetic acid (IAA) amount produced by the green microalga Scenedesmus obliquus culture was detected by high performance liquid chromatography (HPLC). It was evaluated the effect of three process variables in the extracellular IAA production in these cultures using $2^{3}$ factorial design for screening methodology. The experimental design variables were agitation, illuminance (intensity of luminous flux) and carbon source $\left(\mathrm{CO}_{2} / \mathrm{air} \mathrm{v} / \mathrm{v}(\%)\right.$ mixture) at three different levels. The IAA concentration and the specific growth rate were used as response variables. The HPLC analyses showed that under experimental conditions, the IAA amount that is released to the medium by $S$. obliquus depends only on the illuminance variable. The light effects and the carbon concentrations in culture medium were significant $(p<0.05)$ for specific growth rate.

Keywords: indoleacetic acid, green microalgae, HPLC, Scenedesmus obliquus

\section{Introduction}

Microalgae are a valuable source of products such as phycobiliproteins, polysaccharides, proteins, hydrogen and other secondary metabolites. ${ }^{1-3}$ Several studies describe the potential use of these microorganisms to produce bioactive compounds of high values. ${ }^{4-7}$ Current applications for the isolated chemical compounds from various kinds of algae are enormous, and within those, ecological and functional chemistry is outstanding. There is also great potential in developing applications for human and animal nutrition, cosmetics, fatty acids and pigments. ${ }^{8}$ Microalgae are specifically used in the prevention of surface erosion of crops. Species of Chlorophyta and Bacillariophyta are

*e-mail: erlide.prieto@unisabana.edu.co preferentially found in acidic and neutral soils, whereas Cyanobacteria such as Anabaena, Calothrix, Oscillatoria and Nostoc spp. are predominantly found in alkaline soils. ${ }^{9}$

Other functional properties of the extracts of microalgae are related to provide growth factors, which in addition to polysaccharides and macronutrient intakes, they stimulate the growth of rhizospheric microorganisms, promote root growth and decrease the incidence and severity of plant pathogens. These findings are based on accumulated evidence ${ }^{10-12}$ which suggest that some hormones that operate in higher organisms (higher plants) may have a similar role in algae opening a research area with great potential of impact. ${ }^{13}$

In general, it is stated that any chemical is capable of affecting the growth and development of a living organism when used in lower concentrations than those 
required for nutrients. The responses to phytohormones are generally the sum of effects for different combinations of given substance, such as auxin, cytokinins, gibberellins, ethylene, abscisic acid and polyamines, that act jointly or in opposition in complex ways. They also interact with other compounds, i.e., phenols, which according to studies by Kefeli and Dashek, ${ }^{14}$ have protective, stimulatory or inhibitory properties.

The occurrences of biologically active substances which promote the growth of algae and other plant organisms have been reported by many researchers from the marine field. Indole-3-acetic acid (IAA) (one of the main growth regulators of higher plants) belongs to the substances that are detected in seawater and marine sediments. ${ }^{15}$ The indoleacetic acid (known as indole-3-acetic acid) is a natural occurring in most plants. The role of these phytohormones in plant tissue is linked to cell elongation, phototropism, geotropism, apical dominance, root initiation, ethylene production and fruit development, ${ }^{16}$ and they are extensively used in commerce.

In higher plants, IAA is synthesized in chloroplasts of young leaves and induces the process of root formation. Recent data concerning the pathways of phytohormone biosynthesis permit the conclusion that, in most cases, it is connected with chloroplasts. In the 1960s, it was found that auxins and their inactive analogs were present in brown (Macrocystis and Laminaria), red (Botryocladia), and green (Enteromorpha, Chlorella, and Cladophora) algae and also in cyanobacteria (Oscillatoria). ${ }^{17}$

The production capacity of phytohormones in green algae such as Chlorella sp. and Scenedesmus sp. has been described in several studies, ${ }^{18,19}$ which establish that phytohormones are a good choice for the development of technological application that impacts on agriculture or food.

This study was focused on the evaluation of the role of three growth variables (namely agitation, illuminance and $\mathrm{CO}_{2}$ ) in the growth and production of indole-3-acetic acid by Scenedesmus obliquus. The extracellular indoleacetic acid amount was determined by HPLC (high performance liquid chromatography).

\section{Experimental}

\section{Algal strain and cultivation conditions}

The green microalga Scenedesmus obliquus (UTEX 393) was used as a study organism. The microalga was obtained from UTEX culture collection (University of Texas, Austin, TX, USA). The microalgae were cultivated in Modified Bold $3 \mathrm{~N}$ Medium, ${ }^{20}$ containing $\left(\mathrm{NaNO}_{3}(0.25 \mathrm{~g}), \mathrm{CaCl}_{2} \cdot 2 \mathrm{H}_{2} \mathrm{O}\right.$ $(0.025 \mathrm{~g}), \mathrm{MgSO}_{4} \cdot 7 \mathrm{H}_{2} \mathrm{O}(0.075 \mathrm{~g}), \mathrm{K}_{2} \mathrm{HPO}_{4}(0.075 \mathrm{~g})$,
$\mathrm{KH}_{2} \mathrm{PO}_{4}(0.175 \mathrm{~g}), \mathrm{NaCl}(0.025 \mathrm{~g})$, PVI metal solution $(6 \mathrm{~mL})$, vitamin solution, thiamine $\left(1 \mathrm{~mL}, 6.5 \mathrm{mmol} \mathrm{L}^{-1}\right)$ and biotin $\left(1 \mathrm{~mL}, 0.1 \mathrm{mmol} \mathrm{L}^{-1}\right)$ per $\mathrm{L}$ of medium. All reagents were of analytical grade from Merck $^{\circledR}$. The inoculum was kept in glass jars of $250 \mathrm{~mL}$, which were continuously illuminated with fluorescent lamps, bubbled with $4 \%$ at a constant temperature of $25 \pm 2{ }^{\circ} \mathrm{C}$, up to $1 \times 10^{9}$ cell $\mathrm{mL}^{-1}$. The initial inoculums were $1 \times 10^{4}$ cell $\mathrm{mL}^{-1}$.

\section{Experimental design}

$2 k$ factorial design with $k=3$ factors, such as agitation $\left(\mathrm{R}_{\mathrm{f}}\right.$ in rpm), illuminance ( $\mathrm{I}_{\mathrm{a}}$ in $\left.\mathrm{lx}\right)$ and a source of carbon $\left(\mathrm{C}^{*}\right.$, a mixture of air enriched with $\mathrm{CO}_{2}$ in $\mathrm{v} / \mathrm{v}(\%)$ ), was carried out and analyzed in two levels. It is important to keep in mind that factorial design for screening methodology allows the estimation of main effects and interactions of the first order. In addition, in the design, four experiments (central point) were used to estimate the experimental error in response variables, which were the specific growth rate $\left(\mu\right.$ in day $\left.{ }^{-1}\right)$ and the indoleacetic acid concentration $\left(\mathrm{Y}_{\mathrm{A}}\right.$ in $\left.\mu \mathrm{mol} \mathrm{L} \mathrm{L}^{-1}\right)$. In this way, it was obtained a 12 experiment designs which evaluated 3 factors at 2 levels (Table 1). The analysis of responses for each test was performed using the statistical software Statgraphics Plus 5.0 $0^{\circledR}$.

Table 1. Experimental design used for the indoleacetic acid production by microalga $S$. obliquus

\begin{tabular}{|c|c|c|c|}
\hline \multicolumn{4}{|c|}{ Experimental design } \\
\hline Number of experimental factors & 3 & \multicolumn{2}{|c|}{ kind: factorial } \\
\hline Number of responses & 2 & \multicolumn{2}{|c|}{ name: screening $2^{3}$} \\
\hline Number of experimental runs & 12 & & \\
\hline \multirow{2}{*}{ Factors } & \multirow{2}{*}{ Units } & \multicolumn{2}{|c|}{ Experimental } \\
\hline & & Low $(-1.0)$ & Upper (1.0) \\
\hline Intensity of luminous flux $\left(I_{a}\right)$ & lx & 5000 & 11000 \\
\hline Carbon source $\left(\mathrm{CO}_{2}\right)$ & $\mathrm{v} / \mathrm{v}(\%)$ & 0 & 4 \\
\hline Flow regime $\left(\mathrm{R}_{\mathrm{f}}\right)$ & rpm & 0 & 1200 \\
\hline \multicolumn{4}{|l|}{ Response variables: } \\
\hline Indoleacetic acid concentration $\left(\mathrm{Y}_{\mathrm{A}}\right)$ & \multicolumn{3}{|c|}{$\mu \mathrm{mol} \mathrm{L}-1$} \\
\hline Specific growth rate $(\mu)$ & \multicolumn{3}{|c|}{ day $^{-1}$} \\
\hline
\end{tabular}

\section{Growing conditions}

Kontes cultivation vessels of $500 \mathrm{~mL}$ were used for the development of these assays. These were kept at a constant temperature of $27 \pm 2{ }^{\circ} \mathrm{C}$. The agitation $\left(\mathrm{R}_{\mathrm{f}}\right)$ to change the flow regime was performed with a magnetic stirrer. The illuminance was measured at the geometrical center of each container with a Minipa light meter (MLM 1010) and the 
illuminance was adjusted by modifying the capacity (W) of the light source. It was used $42 \mathrm{~W}$ lamps that were initially located at $10 \mathrm{~cm}$ from the bottles for growth. The carbon concentration in the mixture $\mathrm{C}^{*}\left(\mathrm{CO}_{2} \mathrm{v} / \mathrm{v}(\%)\right)$ was controlled by the pressure adjustment in the system discharge control. The air was supplied by a compressor and the carbon dioxide was used at a concentration of $99 \%$. The flows were monitored by a manometer with measuring range between 0-20 psi for air flow and 0-14 psi for the flow of $\mathrm{CO}_{2}$.

\section{Monitoring of biomass in culture medium}

Biomass values $\left(\mathrm{Y}_{\mathrm{c}}\right.$ in cell $\left.\mathrm{mL}^{-1}\right)$ were quantified using a particle counter (Beckman, USA) with duplicate readings. In addition, the cell concentration measurements were validated by measuring the optical density of the culture at $560 \mathrm{~nm}$. For the optical density measurements of the culture, glass cuvettes of $1 \mathrm{~cm}^{3}$ were used, and the absorbance measurements performed on a Varian-Cary 100 spectrophotometer equipped with lamps for the visible and UV regions.

The biomass values and the exponential regressions were used to calculate the maximum specific growth rate $\left(\mu_{\max }\right.$ in day $\left.{ }^{-1}\right)$ using equation $1,{ }^{21}$ during the exponential growth phase in culture.

$\mu=\frac{\ln \mathrm{N}_{\mathrm{t}}-\ln \mathrm{N}_{0}}{\Delta \mathrm{t}}$

where $\mu=$ specific growth rate, $N_{t}=$ population size at the end of the time interval, $\mathrm{N}_{0}=$ population size at the beginning of the time interval and $\Delta \mathrm{t}=$ time interval.
Sample preparation, determination of indoleacetic acid concentration

A $10 \mathrm{~mL}$ of clarified supernatant were adjusted to pH 3.2 with $\mathrm{HCl}$ and extracted three times using $10 \mathrm{~mL}$ dichloromethane in each extraction. The extract was retroevaporated to eliminate the solvent. In parallel, the recovery took place with percentage of $98 \%$. The indol compounds were dissolved in $1.0 \mathrm{~mL}$ methanol/acetic acid solution and analyzed by HPLC. ${ }^{22}$ The resulting solution was injected into a BAS HPLC system consisting of model PM-80, UV-Vis detector ProStar 325 (Varian), autosampler ProStar 410 (Varian). Chromatographic separation was performed on analytical column Microsorb MV 100-5 C18 $(150 \mathrm{~mm} \times 4.6 \mathrm{~mm})$, eluted with methanol/ $/ 0.2 \mathrm{~mol} \mathrm{~L}^{-1}$ acetic acid $\mathrm{pH} 2.8$ (40:60) with isocratic elution at a flow rate of $1.0 \mathrm{~mL} \mathrm{~min}^{-1}$ at room temperature. The IAA presence was detected at $280 \mathrm{~nm}$ wavelength for $15 \mathrm{~min}$. The IAA concentration was calculated using the peak area and the calibration curve between $0.010-0.5 \mathrm{mmol} \mathrm{L}^{-1}$. Each standard of calibration curve was injected by triplicates. Each extract was run with duplicates. The calibration curve equation was $\mathrm{Y}=98.121 \mathrm{X}-0.0032\left(\mathrm{R}^{2}=0.9987\right)$, where $\mathrm{Y}$ is the peak area and $\mathrm{X}$ is the indoleacetic acid concentration $\left(\mathrm{mmol} \mathrm{L}{ }^{-1}\right)$. The limits of detection and of quantification of the method were 0.571 and $1.08 \mu \mathrm{mol} \mathrm{L} \mathrm{L}^{-1}$, respectively.

\section{Results and Discussion}

The consolidated results for each of the experimental runs are shown in Table 2. When the microalga S. obliquus

Table 2. Results of cell growth and IAA concentration in different experimental runs for the microalga S. obliquus

\begin{tabular}{|c|c|c|c|c|c|}
\hline \multirow{2}{*}{$\begin{array}{l}\text { Experimental } \\
\text { runs }\end{array}$} & \multicolumn{3}{|c|}{ Discretized factors } & \multicolumn{2}{|c|}{ Response variable } \\
\hline & $I_{a}(A)^{a}$ & $\mathrm{C}^{*}(\mathrm{~B})^{\mathrm{b}}$ & $\mathrm{R}_{\mathrm{f}}(\mathrm{C})^{\mathrm{c}}$ & $\mu /$ day $^{-1} \mathrm{~d}$ & $\mathrm{Y}_{\mathrm{A}} /\left(\mu \mathrm{mol} \mathrm{L} \mathrm{L}^{-1}\right)^{\mathrm{e}}$ \\
\hline 1 & 1 & 1 & 1 & 0.66 & 2.306 \\
\hline 2 & 1 & -1 & 1 & 0.39 & 3.147 \\
\hline 3 & 1 & -1 & -1 & 0.35 & 4.000 \\
\hline 4 & -1 & 1 & 1 & 0.42 & 2.679 \\
\hline 5 & -1 & -1 & 1 & 0.27 & 1.457 \\
\hline 6 & 0 & 0 & 0 & 0.36 & 1.539 \\
\hline 7 & 1 & 1 & -1 & 0.62 & 2.442 \\
\hline 8 & -1 & -1 & -1 & 0.32 & 1.118 \\
\hline 9 & -1 & 1 & -1 & 0.42 & 2.286 \\
\hline 10 & 0 & 0 & 0 & 0.36 & 1.486 \\
\hline 11 & 0 & 0 & 0 & 0.35 & 2.975 \\
\hline 12 & 0 & 0 & 0 & 0.37 & 2.298 \\
\hline
\end{tabular}

alluminance (lx); ${ }^{\mathrm{b}}$ carbon source (mixture air/ $\mathrm{CO}_{2} \mathrm{v} / \mathrm{v}(\%)$ ); ${ }^{\mathrm{c} f l o w}$ regime (rpm); dindoleacetic acid (IAA) concentration in supernatant; ${ }^{\mathrm{e}}$ specific growth rate. 
grew in conditions where all variables were placed in their lowest levels, the IAA concentration was the lowest $\left(1.118 \mu \mathrm{mol} \mathrm{L} \mathrm{L}^{-1}\right)$.

\section{Specific growth rate $\left(\mu\right.$ in day $\left.{ }^{-1}\right)$ as a response variable}

The experimental design shows that the light effects $\left(\mathrm{I}_{\mathrm{a}}\right)$ and the carbon source concentration in culture medium are significant $(p<0.05)$ (Table 3$)$.

Table 3. Analysis of variance for the experimental design of screening for the microalga $S$. obliquus. Specific growth rate $\left(\mu\right.$ in day $\left.{ }^{-1}\right)$ as a response variable

\begin{tabular}{lccc}
\hline Source & Sum of square & Mean square & $p$-Value \\
\hline A: flux $\left(\mathrm{I}_{\mathrm{a}}\right)$ & 0.0435125 & 0.0435125 & 0.0110 \\
B: $\mathrm{CO}_{2}\left(\mathrm{C}^{*}\right)$ & 0.0780125 & 0.0780125 & 0.0033 \\
C: agitation $\left(\mathrm{R}_{\mathrm{f}}\right)$ & 0.0001125 & 0.0001125 & 0.8493 \\
AB & 0.0105125 & 0.0105125 & 0.1109 \\
AC & 0.0021125 & 0.0021125 & 0.4256 \\
BC & 0.0003125 & 0.0003125 & 0.7523 \\
\hline
\end{tabular}

R-squared $=90.5467 \%$.

However, the results show that the flow regime $\left(\mathrm{R}_{\mathrm{f}}\right)$ has low effect $(p>0.05)$. This explains the low relevance of this variable in the cell growth. In consequence, it can be determined that besides the broad significance of the variables $I_{a}$ and $C^{*}$, all their interactions have direct and positive effect for maximizing the specific growth rate (Figure 1).

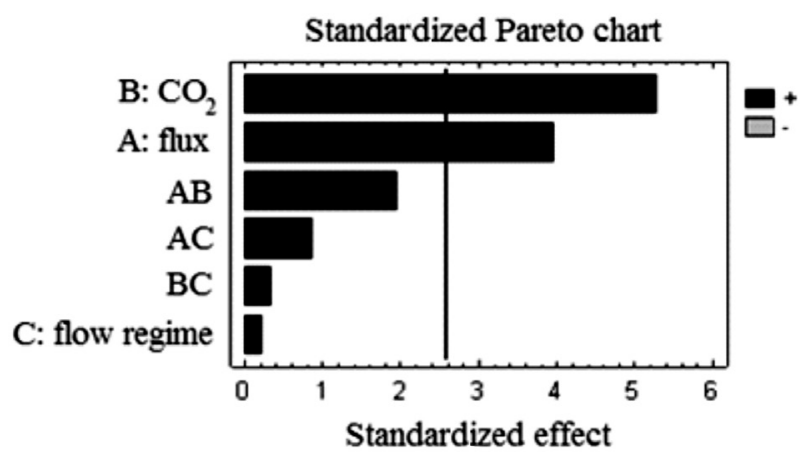

Figure 1. Pareto diagram for the study of growth factors: illuminance (A), carbon source $(B)$ and flow regime $(C)$ on the specific growth rate $(\mu$ in day $^{-1}$, response variable) for the microalga $S$. obliquus.

Therefore, it is clear that the dynamics of the chemical reactions in photobiological processes are directly related to the supply of $\mathrm{CO}_{2}$ and the intensity of the light source. In conditions of relatively constant temperature and $\mathrm{pH}$, these factors would control processes or reactions that are related to the productivity of the culture. The value of the R-squared statistic supports this statement since the obtained results explain $90.55 \%$ of the variability of the specific growth rate.

According to the interaction effects between experimental factors on the response, $\mathrm{AB}$ interaction shows that maximum levels of $\mathrm{CO}_{2}$ and light maximize the productivity of cells. The same effect was noted with $\mathrm{AC}$ interactions (carbon source and flow regime) and $\mathrm{BC}$ (illuminance and flow regime), which at maximum levels also generate this effect (Figure 2).

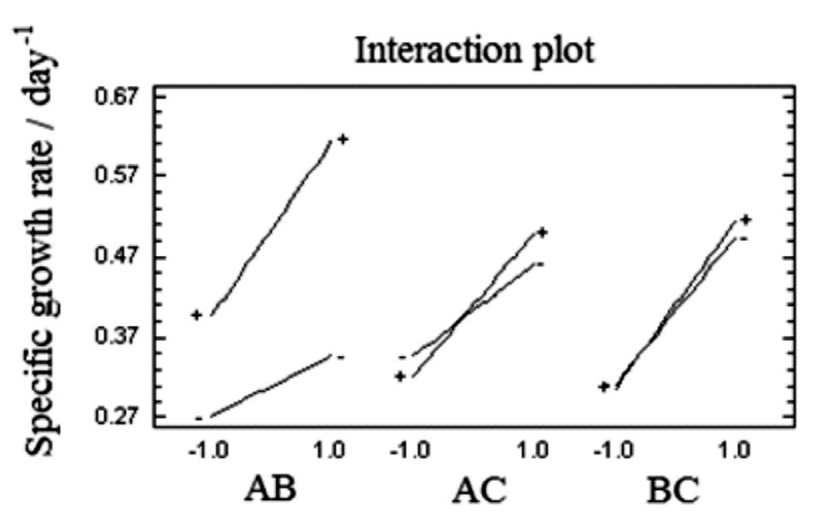

Figure 2. Interaction diagram for the study of growth factors: illuminance (A), carbon source (B) and flow regime (C) on the specific growth rate ( $\mu$ in day ${ }^{-1}$, response variable) for the microalga $S$. obliquus.

Much of the flow regime effect (interactions AC, BC) could be associated with mechanical process that are related to the physiology and cell stability in culture medium. However, in production systems of photoautotrophs, the flow dynamics affect the distribution of light that is associated with the scattering cell in the medium and the self-shading effects that are generated in high density cultures.

$\mathrm{AC}$ interaction can be associated with the effect of hydrodynamics creating different light cycles (light-dark cycles (L/D)). These affect the light energy that is supplied to microalgae. The intermittent lighting in photoautotroph microorganism cultures is analogous to energy source that is used in heterotrophic culture, as proposed by Lee and Pirt. ${ }^{23}$

When the culture had a constant cell density, it was evident that those cells which are submitted to a turbulent flow regime show much shorter L/D cycles than those that handle a flow regime less turbulent or laminar. The productivity $(\mu)$ in relation to the $\mathrm{L} / \mathrm{D}$ cycles is greatly affected not only by the light intensity, but also by the turbulence. As higher the intensity is as shorter is the cycle. In other words, when the light is more intense, the system must provide longer periods of darkness to avoid loss of productivity-development. This has been shown in studies by $\mathrm{Wu}$ and Merchuk. ${ }^{24}$ 
Indoleacetic acid concentration $\left(Y_{A}\right.$ in $\mu$ mol $\left.L^{-1}\right)$ as response variable

The experimental design shows that the light effects $\left(I_{\mathrm{a}}\right)$ in culture medium are significant $(p<0.05)$ (Table 4).

Table 4. Analysis of variance for the experimental design of screening for the microalga $S$. obliquus. Indoleacetic acid concentration $\left(\mathrm{Y}_{\mathrm{A}}\right.$ in

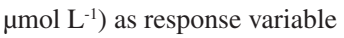

\begin{tabular}{lccc}
\hline Source & Sum of square & Mean Square & $p$-Value \\
\hline A: flux $\left(\mathrm{I}_{\mathrm{a}}\right)$ & 20.2853 & 20.2853 & 0.0031 \\
$\mathrm{~B}: \mathrm{CO}_{2}\left(\mathrm{C}^{*}\right)$ & 4.5286 & 4.5286 & 0.0532 \\
C: agitation $\left(\mathrm{R}_{\mathrm{f}}\right)$ & 2.9585 & 2.9585 & 0.0974 \\
$\mathrm{AB}$ & 0.0234 & 0.0234 & 0.8633 \\
$\mathrm{AC}$ & 1.2760 & 1.2760 & 0.2388 \\
$\mathrm{BC}$ & 1.6993 & 1.6993 & 0.1835 \\
\hline
\end{tabular}

R-squared $=89.608 \%$.

According to the obtained results, it was established that the only affecting and significant factor in the indoleacetic acid production in culture medium of microalgae $S$. obliquus was $\mathrm{I}_{\mathrm{a}}$ (illuminance), presenting a $p$-value $<0.05$. However, the values of $\mathrm{B}\left(\mathrm{CO}_{2}\right)$ and $\mathrm{C}$ (flow regime) registered negative effects on the indoleacetic acid concentration (Figure 3). This behavior was also evident in the $\mathrm{AC}$ and $\mathrm{AB}$ interactions. As a result, it was concluded that illuminance was highly significant but may affect the biomolecule production.

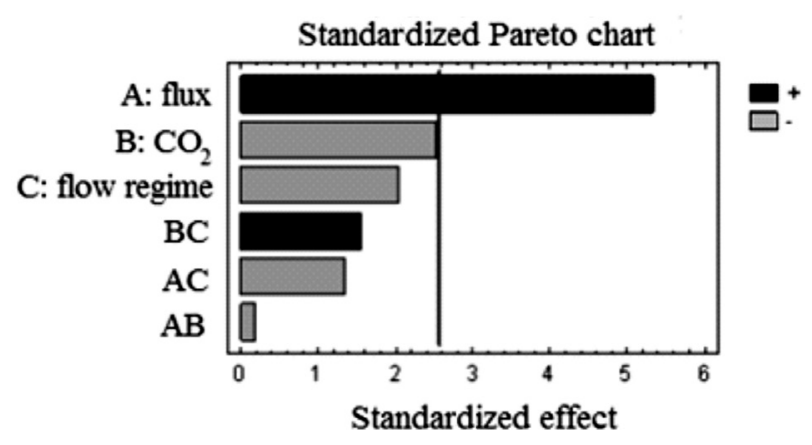

Figure 3. Pareto diagram for the study of growth factors: illuminance (A), carbon source $(B)$ and flow regime $(C)$ on the IAA concentration $\left(\mathrm{Y}_{\mathrm{A}}\right.$ in $\mu \mathrm{mol} \mathrm{L}{ }^{-1}$, response variable) for the microalga $S$. obliquus.

The interactions of the factors on the variable response (IAA) (Figure 4), in which the luminous flux (AB and AC) was present, showed a positive slope that maximized the response variable $\left(\mathrm{Y}_{\mathrm{A}}\right)$. However, it should be noted that the optimum response for each of these interactions is at the minimum level of these factors. Therefore, it can be established that the luminous flux positively stimulates the IAA production since its higher energy availability facilitates processes that are related with carbon sequestration and molecular synthesis.

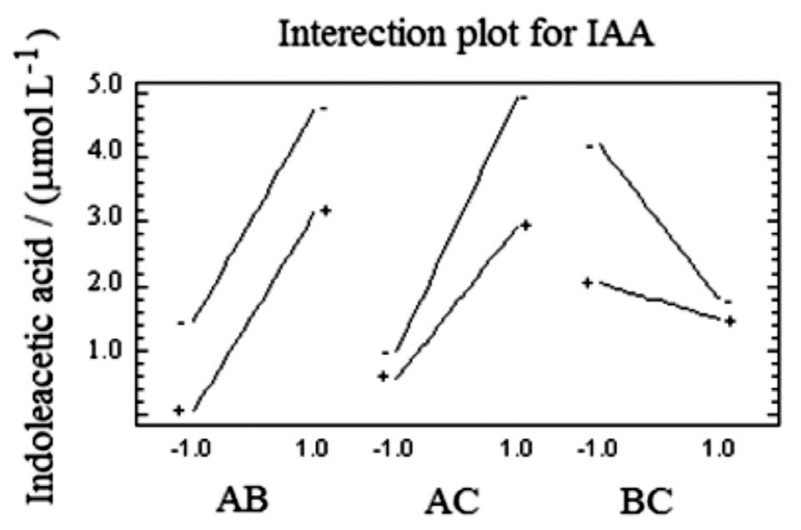

Figure 4. Interaction diagram for the study of growth factors: illuminance (A), carbon source (B) and flow regime (C) on the indoleacetic acid $\left(\mathrm{Y}_{\mathrm{A}}\right.$ in $\mu \mathrm{mol} \mathrm{L} \mathrm{L}^{-1}$, response variable) for the microalga $S$. obliquus.

The results showed that under optimal design conditions (nutrients abundance and homogeneous mixing associated to high values of carbon concentration and flow regimes), the cell does not need to produce secondary metabolites, such as IAA to ensure cell growth. Under adverse conditions, however, the excretion of these substances would be crucial as it would improve the efficiency of photosynthetic processes for generating the energy that is required for maintenance and cell viability. This relationship is justified by a negative effect on the response of factors $\mathrm{B}$ and $\mathrm{C}$ since their abundance or increase would be basically a suppressor for the extracellular IAA overproduction. These stress conditions (without stirring and nutrient depletion), that maximize the IAA production, have been also found in the diatom Skeletonema costatum. ${ }^{16}$

It was established a first-degree polynomial model for the specific growth rate and IAA as response variables, which were calculated from regression coefficients of the experimental design. The obtained equations and their ratios are shown below

$$
\begin{aligned}
& \mu=0.40750+0.07375 \mathrm{I}_{\mathrm{a}}+0.09875 \mathrm{C}+0.03625 \mathrm{I}_{\mathrm{a}} \mathrm{C}+ \\
& 0.01625 \mathrm{I}_{\mathrm{a}} \mathrm{R}_{\mathrm{f}}
\end{aligned}
$$

$\mathrm{Y}_{\mathrm{A}}=5.76950+1.59237 \mathrm{I}_{\mathrm{a}}-0.75238 \mathrm{C}-0.60813 \mathrm{R}_{\mathrm{f}}-$ $0.39938 \mathrm{I}_{\mathrm{a}} \mathrm{R}_{\mathrm{f}}+0.46088 \mathrm{C} \mathrm{R}_{\mathrm{f}}$

Where $\mu=$ specific growth rate $\left(\right.$ day $\left.^{-1}\right), Y_{A}=$ indoleacetic acid concentration $\left(\mu \mathrm{mol} \mathrm{L}^{-1}\right), \mathrm{I}_{\mathrm{a}}=$ light flux/illumination used for growing the photoautotrophic cultures (lx), $\mathrm{C}=$ concentration of the carbon source supplied to the medium (air- $\mathrm{CO}_{2}$ mixture $\mathrm{v} / \mathrm{v}(\%)$ ) and $\mathrm{R}_{\mathrm{f}}=$ shaking/flow regime that the medium is subjected (rpm). 
The obtained extracts from each of the experimental runs were analyzed by HPLC (wavelength of $280 \mathrm{~nm}$ ). Due to the low IAA concentration in culture medium, it had to be prior extracted with dichloroethane. The volume of $20 \mu \mathrm{L}$ of each concentrated and treated supernatant was previously injected. It was found that the greatest IAA amount was identified in the supernatant of the sample in which the illuminance was kept at its maximum (11000 lx) and $\mathrm{CO}_{2}$ concentration and agitation were located at their lowest values, i.e., $0 \% \mathrm{CO}_{2}$ and without agitation. Under these conditions, the detected IAA concentration was $4.0 \mu \mathrm{mol} \mathrm{L}{ }^{-1}$ (Figure 5).
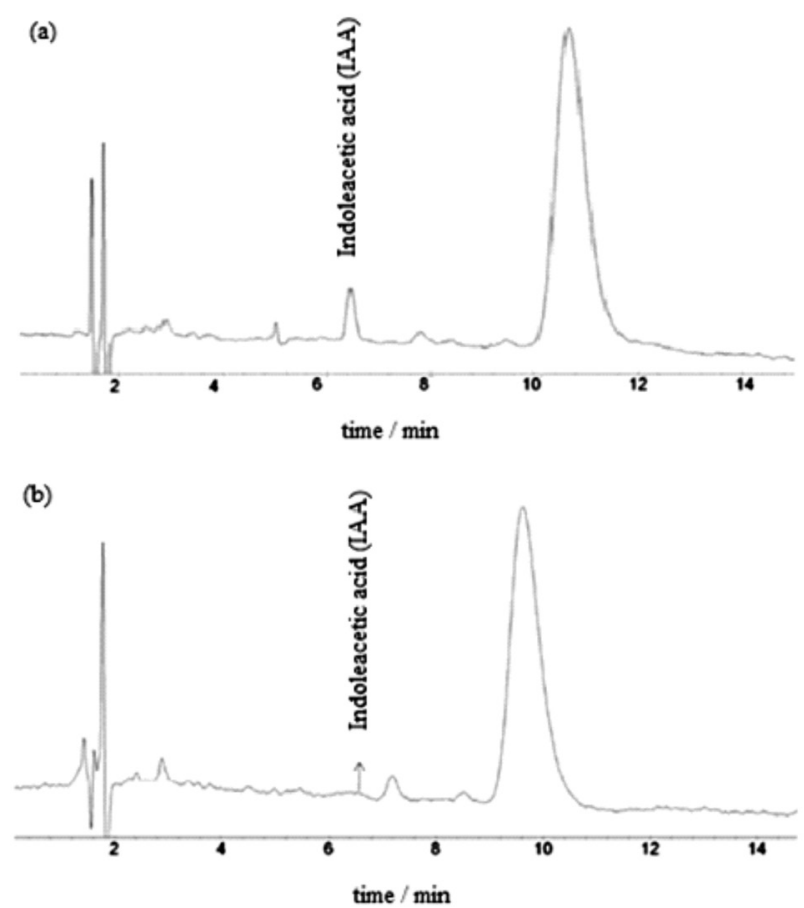

Figure 5. HPLC chromatograms identifying IAA by UV spectrum ( $280 \mathrm{~nm}$ ) of (a) S. obliquus culture medium with higher IAA concentration and (b) S. obliquus culture medium extract in standard conditions of growth (IAA not detectable).

HPLC analysis shows the presence of IAA in culture medium of S. obliquus. This is consistent with studies by Mazur et al. ${ }^{15}$ in which the presence of this phytohormone in extracts of Scenedesmus armatus and Chlorella pyrenoidosa (identified by HPLC with diode array detector (DAD)) allowed the authors to conclude that the unicellular green algae endogenously synthesized IAA.

\section{Relationship between specific growth coefficient $\left(\right.$ day $\left.^{-1}\right)$ and IAA production $\left(\mu \mathrm{mol} L^{-1}\right)$}

The relationship between cell production and IAA in culture medium according to reported data in this investigation did not show a direct relationship between them since a high cell yield does not necessarily generate greater IAA amount in culture medium (Figure 6). These results are associated with a previous work in which it was found that slow growth cells (productivity) is associated with the higher release of metabolites in culture medium..$^{25}$

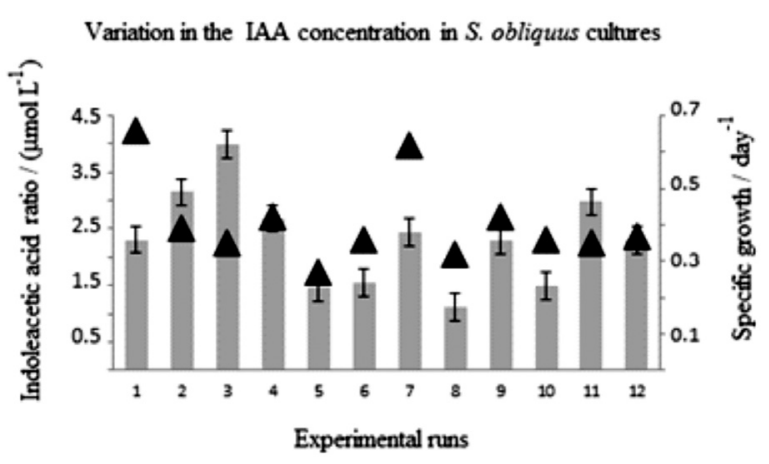

Figure 6. Relationship between the specific growth coefficient and the IAA concentration in different experimental runs for the microalga $S$. obliquus. $\mathbf{\Delta}$ = specific growth coefficient

Mazur et al. ${ }^{15}$ quantified the IAA concentration by HPLC with DAD in culture medium of two Chlorophyta microalgae (Scenedesmus armatus and Chlorella pyrenoidosa). In this study, ${ }_{15}$ it was shown that the IAA amounts in culture medium were related to cell responses due to environmental and physiological changes. These results support the findings in our investigation.

\section{Conclusions}

Scenedesmus obliquus (UTEX 393) was able to produce different IAA concentrations when it was grown under phototrophic conditions, suggesting that it is a potential source for obtaining this type of phytohormone. The extracellular IAA production in this microalga is mainly associated with stress conditions. Higher IAA production was archieved when illuminance was set at $11000 \mathrm{~lx}$ (the highest level), in absence of $\mathrm{CO}_{2}$ and stirring of culture medium, demonstrating that the luminous flux is relevant to the production of this biomolecule.

The IAA quantification by HPLC UV-Visible was consistent with reported results by other detectors, allowing us to establish that this technique is a reliable tool in determining this kind of biomolecule. The highest IAA concentration in culture medium was $4.0 \mu \mathrm{mol} \mathrm{L} \mathrm{L}^{-1}$. However, much research is needed to optimize the IAA production process and to achieve higher concentration that makes suitable an industrial-commercial scale production.

\section{Acknowledgements}

We are thankful to Colciencias (Departamento Administrativo de Ciencia, Tecnología e Innovación), 
Live Systems Technology S. A. and Fondo Patrimonial Universidad de La Sabana.

\section{References}

1. Skulberg, O. M. In Bioactive Chemicals in Microalgae; Richmond, A., ed.; CRC Press: Florida, 2004, ch. 30.

2. Ördög, V.; Stirk, W. A.; Lenobel, R.; Bancírová, M.; Strnad, M.; Van Staden, J.; Szigeti, J.; Németh, L.; J. Appl. Phycol. 2004, $16,309$.

3. Roeselers, G.; Van Loosdrecht, M. C; Muyzer, G.; J. Appl. Phycol. 2008, 20, 227.

4. Borowitzka, M. A.; Curr. Microbiol. 1986, 3, 372.

5. Bubrik, P.; Bioresour. Technol. 1991, 38, 237.

6. Pulz, O.; Appl. Microbiol. Biotechnol. 2001, 57, 287.

7. Banerjee, A.; Sharma, R.; Chisti, Y.; Banerjee, U. C.; Crit. Rev. Biotechnol. 2002, 22, 245.

8. Spolaore, P.; Joanniss-Cassan, C.; Duran, E.; Isambert; A.; J. Biosci. Bioeng. 2006, 101, 87.

9. Pimentel, D.; Garnick, E.; Berkowitz, A.; Jacobson, S.; Napolitano, S.; Black, P.; Valdes-Cogliano, S.; Vinzant, B.; Hudes, E.; Littman S.; Bioscience 1980, 30, 750.

10. Buggeln, R. G. In Morphogenesis and Growth Regulators; Lobban, C. S; Winne, M. J, eds.; University of California Press: Berkeley, 1981, ch. 18.
11. Jacobs, W. P In Plant Growth Substances. Bopp, M.; eds.; Springer-Verlag: Berlin, 1985, ch. 12.

12. Evans, L. V.; Trewavas, A. J.; J. Phyco. 1991, 27, 322.

13. Bradley, P. M.; J. Phycol. 1991, 27, 317.

14. Kefeli, V. I; Dashek, W. V; Biol. Rev. 1984, 59, 273.

15. Mazur, H.; Konop, A.; Synak, R.; J. Appl. Phycol. 2001, 13, 35.

16. Bentley-Mowat, J. A.; Wiss. Z. Univ. Rostock, Math. Naturwiss. Reihe. 1967, 16, 445.

17. Tarakhovskaya, E. R.; Maslov, Y. I.; Shishova, M. F.; Russ. J. Plant Physiol. 2007, 54, 163.

18. Stirk, W. A.; Ördög, V.; Van Staden, J.; Jäger, K.; J. Appl. Phycol. 2002, 14, 215.

19. Bailey, D.; Mazurak, A. P.; Rosowski, J. R.; J. Phycol. 1973, 9 , 99.

20. Nichols, W. H.; Bold, H. C.; J. Phycol. 1965, 1, 34.

21. Wood, A. M.; Everroad, R. C.; Wingard, L. M. In Measuring Growth Rates in Microalgal Cultures; Andersen, R. A., eds.; Academic Press: USA, 2005, ch. 18.

22. Chung, K. R.; Tzeng, D. D.; J Biol Sci. 2004, 4, 744.

23. Lee, Y. K.; Pirt, S. J.; J. Gen. Microbiol. 1981, 124, 926.

24. Wu, X.; Merchuk, J. C.; Chem. Eng. Sci. 2001, 56, 3527.

25. Allard, B.; Tazi, A.; Phytochemistry. 1993, 32, 41.

Submitted: March 30, 2011

Published online: November 8, 2011 